\title{
Determinants of Ethiopian Flower Export Performance: The Case of Gravity Model Application
}

\author{
Fisseha Seyoum \\ Department of Agricultural Economics and Agribusiness Management, Haramaya University, Haramaya, Ethiopia
}

\section{Email address:}

Fissehaseyoymtullu@gmail.com

\section{To cite this article:}

Fisseha Seyoum. Determinants of Ethiopian Flower Export Performance: The Case of Gravity Model Application. International Journal of Finance and Banking Research. Vol. 7, No. 5, 2021, pp. 101-110. doi: 10.11648/j.ijfbr.20210705.11

Received: May 10, 2021; Accepted: August 18, 2021; Published: September 23, 2021

\begin{abstract}
In contemporary economic activities, international trade is evolved from perfect protection to perfect free global trade among countries to bring balanced. International trade in general and export in particular is the most important economic activities to secure economic growth and development. However, sub-Saharan African countries including Ethiopia exports agricultural products balky in volume low in value leads to low performance and also low in diversity. To improve Ethiopian export performance, the government has been taking different policy options among them is export diversification. Flower commodity export is one of the diversification policy options. Each commodity export has its own constraints and opportunities affecting its export performance. The objective of this paper was to identify factors affecting flower export performance in the Ethiopian economy using five years balanced panel data ranging between 2010 and 2014 to Ethiopian flower importing countries. The result of the statistical analysis indicated that even though there is variation among years, the average five years export performance was about $\$ 4.79$ million from exporting about 96.48 tons of flowers. The result of the gravity model econometric regression results revealed that domestic gross product (GDP) and the domestic population growth had positive effects while the exchange rate had a negative effect on the Ethiopian export performance dynamics. The result, it is suggests that all the factors affecting Ethiopian flower export performance are domestic factors or supply side factors. Therefore, the export economic policy should focus on boosting the GDP, efficient and effectiveness of human power through education and training, and stabilizing the exchange rate to enhance the Ethiopian flower export performance in particular and national export performance in general.
\end{abstract}

Keywords: Gravity Model, Flower, Export, GDP, Exchange, Ethiopia

\section{Introduction}

Economic growth leading to development is the fundamental objective of every society in the world. Among many variables contributing to economic growth and development, export of goods and service is considered as the most important accelerators of economic growth providing the source of exchange, and employment, improves the national balance of payment, facilitate technological transfers, increase the size of the market and enhances the international competitiveness of a country [1].

African countries have been failed to succeed in export performance mainly because of the wrong backward policies and strategies. The failure of backward in-ward looking policy to stimulate the desired economic growth in the 1960 s and 1970s had led most African countries to rethink the new appropriate trade policy and strategies. Since the 1980s, the trade and development strategy of Sub-Saharan African countries has been changing in favor of export orientation and trade liberalization to overcome the inherent limitations and its adverse effects of the import substitution and protection type of industrialization strategy [47, 48].

Over the last two decades, developing countries' contribution to global trade has risen steadily from just under a quarter to almost one-third. The diversity of their exports has aided their increased engagement in global trade. Manufacturing's proportion of developing countries' total goods exports climbed from 35.1 percent in 1985 to 65.8 percent in 2004, while manufacturing's part of world exports increased from 14.5 percent in 1985 to 30.3 percent in 2005 . In addition, developing countries have broadened their export markets. The share of developing country markets in total 
Exports from developing countries climbed from $27.8 \%$ in 1990 to $39.4 \%$ in 2004 . One of the most important factors to examine when evaluating a country's export performance is its contribution to the overall GDP. If its contribution to national GDP percentage is high, it is assumed that the country is heavily involved in export trade and benefited greatly from it. If it is low, it could indicate that the country is less involved in exporting or it does not produce enough cash from its exports [49].

Developing countries have also diversified their export markets. The share of developing Country markets in total exports increased from 27.8 percent in 1990 to 39.4 percent in 2004, but these figures hide important regional differences. Asia's share in the total world exports increased from $11.7 \%$ in 1985 to $21.5 \%$ in 2005 , whereas Africa's share decreased from $4.3 \%$ to $2.9 \%$ over the same period. The share of manufactures in Chinese exports increased from 42.2 percent in 1985 to 71.4 percent in 1990 and 90.6 percent in 2004, their share in African exports increased from 19.9 percent in 1990 to 28.6 percent in 2002 only to fall back to 21.2 percent in 2005 due to the rise in the value of oil exports [8].

Ethiopia has a long history of participating in international trade under several regimes, each with its own set of policies. However, Ethiopia's export business is dominated by the export of a few agricultural commodities, primarily coffee, oilseeds, grains, live animals, chat, flowers, and hides and skins. In the last few years, export performance has been beyond all expectations, reaching a never-before-seen level of $\$ 2$ billion in 2010. This is a significant rise since it represents a 38 percent increase over the $\$ 1.5$ billion in exports recorded the previous year [4, 31, 33, 37].

Ethiopia's share in total world exports is still very low, which is around $0.03 \%$ in $[23,37,46-48]$. It is argued that Ethiopia's external trade has major problems both on the supply side dependence on few primary products and characterized by large fluctuations in volume has a very high degree of concentration of exports on few commodities. Both supply and demand-side problems are typical African problems: For example, more than $50 \%$ of African countries' export earnings are derived from only three principal commodities such as coffee, tropical beverages and cocoa [31, 33, 51].

In the past few years, the Ethiopian government designed policies and strategies that are assumed to improve the export sector. One of the measures taken is export diversification. Based on this measure currently, horticultural industry export in general and flower export program, in particular, is being initiated and the country is exporting to the world market. Periodical policies and strategies evaluation are important for the continuous improvement of an economy and identifying factors, which affect the Ethiopian flower sector, is not yet identified as far as the researcher knowledge. Therefore, the objective of this paper lies in examining the determinant factors affecting the flower export performance of Ethiopia using the gravity model, a known important policy review approach.

\section{Literature Review}

\subsection{International Trade Theory}

Analysis indicated that the export sector of the least developed countries in international trade is driven by enduring national differences in factor advantages and costs $[4,14]$. Ethiopia and Rwanda are coffee exporters because of their soil and climate, Nigeria, Libya and Sudan are oil exporters because of geology, and Uganda is an exporter of maize because of the abundance of land relative to labor. According to Krugman et al., [33], productivity differences and factor endowment causes export performance in international trade. Because of the importance of productivity and factor endowment difference in international trade, the focal point of policies has been toward "competitiveness" in most developing countries.

To discuss competitiveness in international trade both Ricardian and Heckscher-Ohlin trade theories are well-read in most works of kinds of literature. The Ricardian model of trade theory emphasis difference in productivity levels across countries. The model introduces the idea that technological differences across countries matter. Whereas, the Heckscher Ohlin model of trade relies on the difference in relative factor endowment across countries and dispenses with the notion of technological differences. Instead, the model shows how factor endowments form the basis for trade [10, 33, 43].

The Ricardian model faces certain limitations and makes misleading predictions. The simple Ricardian model predicts an extreme degree of specialization that is difficult to observe in the real world. One of which is the case for nontrade goods. Second, the Ricardian model left out the effects of income distribution within countries. Thus, the model predicts that countries as a whole will always gain from trade; in practice, international trade has strong effects on income distribution. Third, the model gives little attention to differences in resources endowment among countries as a cause of trade, thus missing an important aspect of the trading system. Finally, the model neglects the possible role of economies of scale. This retains the limitation that the model is unable to explain the large trade flows between apparently similar nations [10, 33].

The essence of the Heckscher-Ohlin model is attributed to differences in factor abundance across countries. The model states that countries should produce and export those products whose factors of production are abundantly available. Similar to the specific factors, exporters of abundant resources benefit and the less abundant resource lose [43]. The Heckscher-Ohlin model is hopelessly inadequate as an explanation for historical or modern trade patterns unless technological differences across countries are considered [10, 25, 26].

The gravity model is a trade model where the most important empirical approaches have been published. The origin of the model begins with the gravitational law in physics by Isaac Newton, in which the gravitational force of attraction between two objects is proportional to the product of their masses and inversely proportional to the square of the 
distance between them. The econometric studies of trade flow based on the gravity model were made by Tinbergen [44] and Poynohen [7, 39]. However, the model lacks a theoretical basis. Investigations were therefore begun into the theoretical foundations of the gravity equation.

The gravity equation explains bilateral trade flows as a function of the economic size of the two trading partners and the distance between them. This equation has been remarkably successful in numerous empirical applications and the theoretical foundation [5, 12, and 33]. More recently, Anderson [5] focused on the theoretical foundation of the gravity equation. The gravity equation could be derived from trade models with differentiated goods. Feenstra [25] further derived a gravity equation with homogeneous goods; this revealed another kind of product differentiation model coming from factor endowment differences. Deardorff [17, 18] completed the theoretical foundations of the gravity model by showing that the gravity equation is consistent with the Heckscher-Ohlin trade model inhomogeneous goods with perfect competition. Deardorff's findings on the equation can readily be derived from a factor endowments model irrespective of the factor price equalization.

The development of theoretical foundations for gravity equations comes because of several trade models. However, gravity equations could be derived for both differentiated and homogeneous goods, the different theories underlying the equation lead to measurably different estimations in key parameter values $[7,26]$.

Awareness then comes up in identifying the underlying

trade model in gravity estimation. While the HeckscherOhlin theory would account for the success of the gravity equation in explaining bilateral trade flows between countries with large factor proportion differences and high degrees of inter-industry trade. On the other hand, the differentiated product model would serve well in explaining bilateral trade flows between countries with high shares of intra-industry trade in increasing returns with monopolistic competition. Therefore, the different theories underlying the gravity equation lead to different trade policy implications.

Theoretically and empirically, the gravity model has been showing progress and improvement in explaining international trade. The most noted addition of important variables improves the model. Different studies have employed explanatory variables such as population size, GDP per capita, and real exchange rate at different times [7, $27,36]$. Furthermore, several dummy variables have been included to capture geographical, cultural, institutional, and other related aspects that may influence bilateral trade flows between two countries [2, 22].

The gravity model has been able to achieve plenty of applications to various types of inter-regional and international trade flows; gained higher popularity and there are sufficient data ready for use for various areas of research. Hence, gravity model enables to evaluates various trade policies [6, 24], workers remittance [35], immigration [34] and [11] foreign direct investment $[6,19]$, market structure [28], external debt [5, 41, 42].

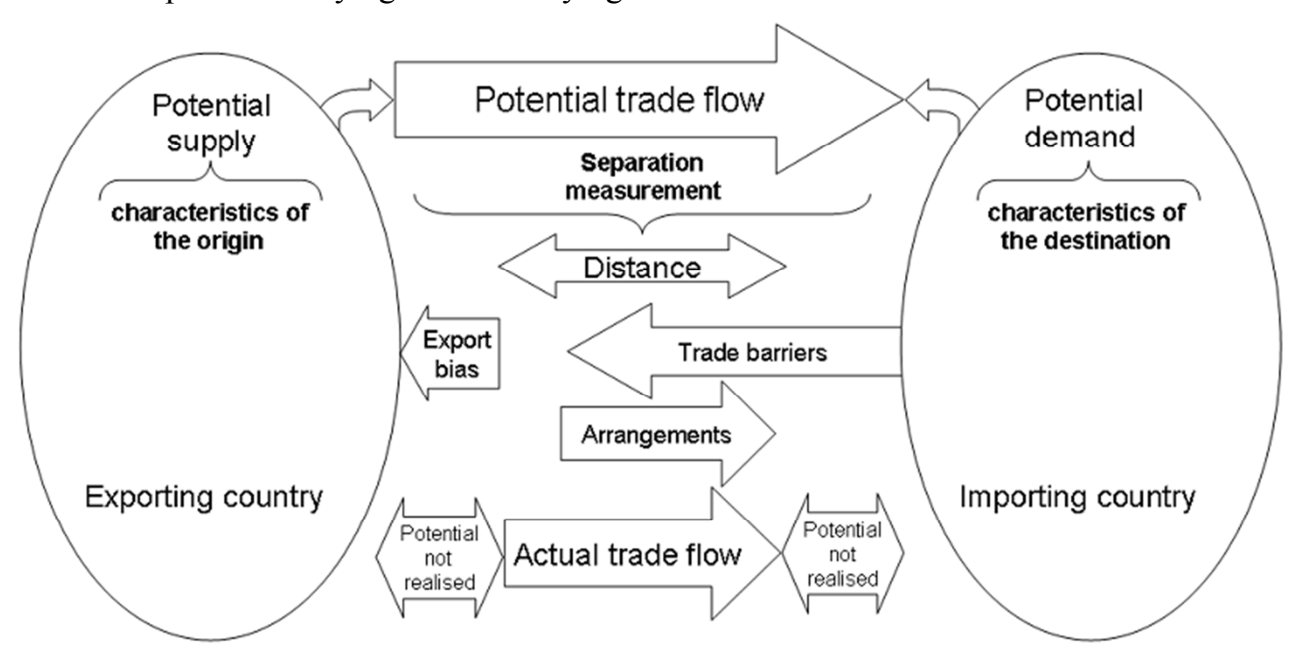

Figure 1. Design of Gravity Model.

\subsection{Gravity Model of International Trade}

The formal explanation of the theory of gravity model was devised to derive the equation $[5,6]$ from the properties of the expenditure system under a hypothesis of identical homothetic preferences across regions. The basic gravity model states that trade flows between two countries are positively affected by the product of the two countries' GDP and negatively influenced by the distance between them [9, 17] and the distance between the two economies is not squared as in the law of gravitational force in physics [7, 20, 4, 45].

The model is specified based on the formulation of Haynes and Fotheringham (1984) which is a simple version of the gravity equation:

$$
X_{i j}=\beta Y_{i} Y_{j} / D_{i j}
$$

Where $X_{i j}$ is the value of exports from the country to country $j, \mathrm{Y}_{\mathrm{i}}$ is the GDP of the exporter country, $\mathrm{Y}_{\mathrm{j}}$ is the GDP of the importer country, $\mathrm{D}_{\mathrm{ij}}{ }^{\mathrm{s}}$ measures the distance between exporting and importing countries and $\beta$ is a constant 
of proportionality.

The model used by $[6,20]$ assuming Cobb-Douglas preferences and then constant elasticity of substitution (CES) preferences. Using the Cobb-Douglas preference, normal trade is specified first in gravity non-linear form as follows:

$$
\mathrm{X}_{\mathrm{ij}}=\beta_{0} \mathrm{Y}_{\mathrm{i}} \beta_{1} \mathrm{Y}_{\mathrm{j}} \beta_{2} \mathrm{P}_{\mathrm{i}} \beta_{3} \mathrm{P}_{\mathrm{j}} \beta_{4} \mathrm{D}_{\mathrm{ij}} \beta_{5} \mathrm{~A}_{\mathrm{ijj}} \beta_{6} \mu_{\mathrm{ij}}
$$

Where $Y_{i}\left(Y_{j}\right)$ indicates the GDP of the exporter and GDP of the importer respectively, $\mathrm{P}_{\mathrm{i}}\left(\mathrm{P}_{\mathrm{j}}\right)$ population of the exporter and importer respectively, $\mathrm{D}_{\mathrm{ij}}$ captures the distance between the two countries, $A_{i j}$ represents any other factors serving or constraining trade between pairs of countries, and $\mu_{\mathrm{ij}}$ is the error term captures random errors that may affect bilateral trade between the two countries. Taking logarithms of both sides of Equation 2, the log log-linear equation is expressed as:

$$
\ln \mathrm{X}_{\mathrm{ij}}=\alpha_{0}+\beta_{1} \ln \mathrm{Y}_{\mathrm{i}}+\beta_{2} \ln Y_{\mathrm{j}}+\beta_{3} \ln \mathrm{P}_{\mathrm{i}}+\beta_{4} \ln \mathrm{P}_{\mathrm{j}}{ }_{\mathrm{ijj}} \mathrm{A}_{\mathrm{ij}}+\beta_{5} \ln \mathrm{D}_{\mathrm{ij}}+\mathrm{u}_{\mathrm{ij}}
$$

In model (3) under $\sum \beta_{\mathrm{ij}} \mathrm{A}_{\mathrm{ij}}$ explanatory variables like exchange rate $\left(\mathrm{e}_{\mathrm{ij}}\right)$, foreign direct and investment $\left(\mathrm{f}_{\mathrm{ij}}\right)$ are augmented and expressed as:

$$
\ln X_{i j}=\alpha_{0}+\beta_{1} \ln Y_{i}+\beta_{2} \ln Y_{j}+\beta_{3} \ln P_{i}+\beta_{4} \ln P_{j}+\beta_{5} \ln D_{i j}+\beta_{6} f_{i j}+\beta_{7} \operatorname{lnexr}_{i j}+u_{i j}
$$

\section{Methodology}

The study focuses on Ethiopian flower export to 46 main trade partners. They were selected based on the fact that they have been consistently trading partners over the past 5 years and have a high percentage contribution to total bilateral trade flow.

\subsection{Sources and Types of Data}

Aggregated secondary data for the study was collected from different sources. Flower importing counties, import quantity and FOB value from 2010 to 2014 five years data was collected from the Ministry of Trade. The data for most of the variables including GDP (in billions of US Dollars), and population size (in millions) have been obtained from the World Bank. From the World Development Indicator database such as real exchange rate and foreign direct investment were obtained from UNCTAD stat.

The distance in kilometres between Addis Ababa and the capital cities of major trading partner countries has been obtained from www.timeanddate.com. Effective trade agreements and other related data were not included in the study given there was no adequate data.

\subsection{Variable Definition}

The data for this panel type study covering from the period 2010 to 2014 using some of the selected variables based on the international trade theory and empirical literature review of the gravity model. In this paper, the dependent variable, the value of Ethiopian flower export in USD $\left(\mathrm{x}_{\mathrm{ij}}\right)$. International trade theories show that there are a large number of factors affecting trade bilateral trade performance, based on the data available the following variables were considered in this seminar paper.

Independent variables were real Exchange rate (exri and exrj): Exchange rate measures the volatility of an economy given that it can affect trade both directly and indirectly. Direct effects can be through uncertainty and adjustment costs, while indirect effects can be through their influence on the structure of output and investment and government policy
$[3,16]$.

Population number $\left(\mathrm{P}_{\mathrm{i}}\right.$ and $\left.\mathrm{P}_{\mathrm{j}}\right)$ : Depending on whether the absorption impact or the economies of scale effect is prominent, the effect of an exporter country's population could be positive or negative. A large population may signify a huge domestic market and abundant natural resources, in which case a larger absorption effect may lead to less export. On the other hand, a large domestic market implies making use of economies of scale for the population coefficient's projected sign to be positive. For similar reasons, absorption effects and economies of scale effects are projected to affect their imports positively and negatively. However, the coefficient of importing country population is uncertain. In the case of the flower, a large population is the source of labor and its resource endowment and positive sign is expected in exporting country.

Distance $\left(D_{i j}\right)$ : it is the distance from Ethiopia exporting country's capital city to $\mathrm{j}$ importing countries in $\mathrm{km}$. Distance is a trading resistance factor that represents trade barriers through transportation costs, delivery time, cultural unfamiliarity and market access. Among other factors, higher transportation costs reduce the volume of trade and increase information costs. Countries with short distances from each other are expected to trade more than those who are wide apart because of reduced transaction costs. The distance can also be used as a proxy for the risks associated with the quality of some of the goods and the cost of the personal contact between managers and customers.

It is based on an assumption that the farther the countries are from Ethiopia, the higher the costs of transportation and vice versa. Therefore, distance is expected to negatively influence the bilateral exports of Ethiopia.

Real Gross Domestic Product (GDP in USD, $\mathrm{Y}_{\mathrm{i}}$ and $\mathrm{Y}_{\mathrm{j}}$ ): GDP of the trading countries represents both the production and consumption capacity that determines largely the trade flow among them. The GDP of an importing country is expected to play a substantial impact in predicting the trade flow coming from exporting countries as a proxy for the economic sizes of the countries. This is because the GDP of the importing country, like the consumer's income, impacts the demand for items produced in exporting countries. The real GDP of an exporting country also aids in determining the 
exporting country's productive capacity, or the number of commodities that could be supplied. According to the gravity model, an exporting country's GDP has an impact on the trade flow of its products and services. As a result, trade flows increase in tandem with the real GDP of any two or more trading countries. Positive Real GDP coefficients are expected as a result $[3,9,14,18,21]$. The factories that affect the export growth vary from one country to country. Many Scholars have grouped the determinants of a country's export growth rate into two major Factors: internal supply and external market conditions [20, 41, 43]. Foreign Direct Investment $\left(\mathrm{f}_{\mathrm{ij}}\right)$ is an Ethiopian annual direct investment in USD to measure the effect of foreign direct investment on export as it is expected to enhance a country's competitiveness on international markets by increasing the technological content of exports. It is included in this study as stock since a stock measures its productive capacity. It is believed that the transformation of the composition of exports increases with the direct investment the signs of this variable is expected to be positive. Data on FDI stock is taken from UNCTAD World Investment Report. For many countries, $\mathrm{f}_{\mathrm{ij}}$ is an important component in determining the supply side of export [49]. Foreign direct investment $\left(\mathrm{f}_{\mathrm{ij}}\right)$ is another important factor affecting the export supply capacity of a country. There is consensus among development economists that $f_{i j}$ inflows are likely to play an important role in explaining the growth of recipient countries $[14,18]$.

\subsection{Estimation Mechanism and Data Stationary Test}

To determine export determinants of Ethiopia's flowers, there are different techniques to use. The gravity model is employed to determine factors affecting the export performance of the country using panel data techniques.

\subsubsection{Panel Data Modeling}

Cross-sectional data have been used in estimating the coefficients in the gravity model traditionally. However, using data collected at a point in time lacks homogeneity among the countries. To mitigate this problem, researchers have turned towards using panel data, allowing the general types of heterogeneity handling [50]. Moreover, Hsiao [30,
32] explain the advantages of using a panel data set over a cross-section and time series. Using a panel data set enable to handle heterogeneity or individual effects, give more informative data, more variability, less collinearity among the variables, more degrees of freedom and more efficiency.

\subsubsection{Fixed Effects Model and Random Effects Model}

The fixed-effects model (FEM) is unrestricted as it allows the intercept and other parameters to vary across trading partners. It is appropriate when the unobservable element $\alpha$ does not vary over time and when the covariance between $\alpha_{i}$ and $\mathrm{X}_{\mathrm{i}}$ is different from 0 that is $\operatorname{cov}\left(\alpha_{\mathrm{i}} \mathrm{X}_{\mathrm{i}}\right) \neq 0$. When the fixed effects model is run, $\hat{\beta}$ is identified from individual variation in $X_{i}$ around the individual mean, i.e. is estimated as a change in $\mathrm{x}$ over time. The $\alpha_{\mathrm{i}}^{\mathrm{s}}$ are unbiased but inconsistent if $\mathrm{T}$ is fixed $[32,39,40]$. The fixed effects capture those factors such as physical distance, the length of the border, history, culture, and language that are constant throughout the data and that are correlated with the volume of bilateral trade. FEM would be a better choice when one is interested in estimating typical trade flows between ex-ante predetermined selections of nations (Egger, 2000).

The random-effects model (REM) treat effects as random absorbed into the error term so it specifies a particularly simple form of the residual covariance structure $\left(=\alpha_{i}+v_{i t}\right)$. It is another form where there is no correlation between individual-specific effects with the independent variables. Coefficients of all variables in the model, time-variant and time-invariant will be estimated. In a random effect, there is no fixed individual-specific effect. The reason behind the random effect model is that, unlike the fixed-effect model, the variation across entities is assumed random and uncorrelated with the explanatory variables included in the model. It is assumed as $\left(x_{i t}, t_{i}\right)=0$.

\section{Result and Discussions}

In this section Ethiopian flower, the export analytical result was discussed used using descriptive statistics and regression analysis. Descriptive statics are presented in the form of Figures and Tables with their elaboration.

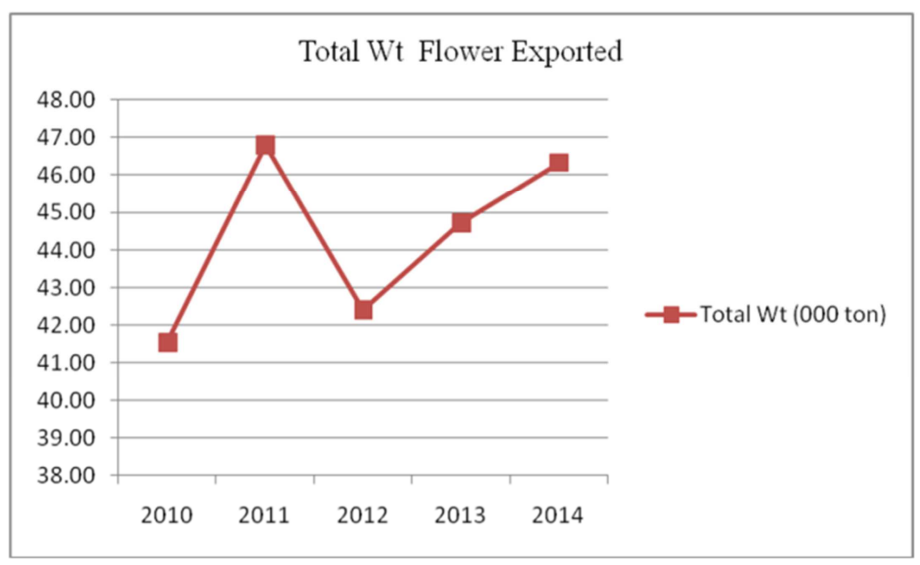

Source: Data from Ministry of Trade

Figure 2. EthiopianFlower Exported (2010-2014). 


\subsection{The Data Analysis Empirical Results and Interpretation}

Figure 2 above indicates that in 2010, Ethiopia was exported more than 42,000 tons of flowers and in 2011; it exported 47,000 tons of flowers. In 2012 it was declined to around 42,000 tons of flowers. From the Figure above, it can be seen that the flower export business is fluctuating. This means that factors are affecting positively and negatively the Ethiopian flower export. During 2011 around 48,000 tons of cut flower was exported and in the next year, this Figure was a decline by more than 3000 tons of flower and again start to increase in 2013 and 2014.

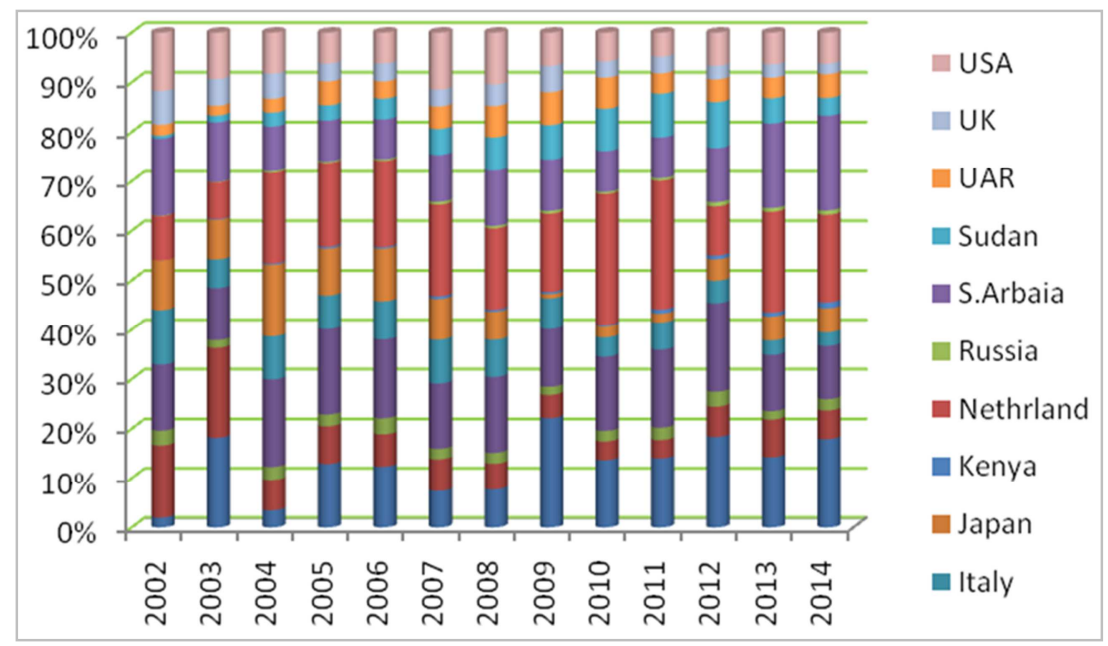

List of importing markets for a product exported by Ethiopia in 2014 Product : TOTAL All products

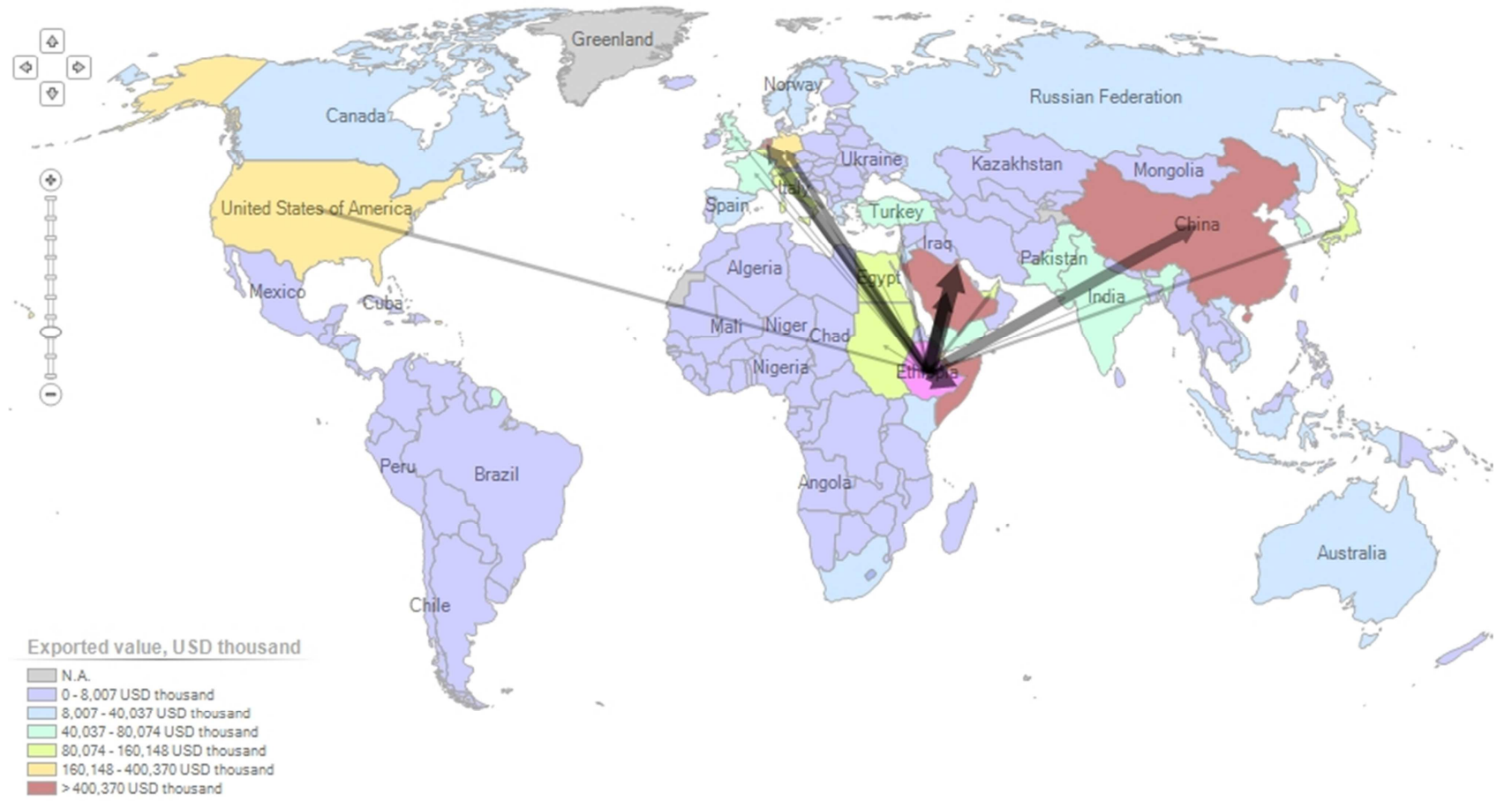

Source: Data from Ministry of Trade.

Figure 3. Value of Ethiopian Flower Exported (2010-2014).

As can be seen from Figure 3 above, Ethiopia obtained around 175 million USD during 2010 and more than 200 million in 2014 from flower export. From Figures 2 and 3 above, it can be observed that the exported flower quantity Figure and export value follow a similar pattern. 
Table 1. Descriptive Analysis Short Balanced Data of Ethiopian Flower Export.

\begin{tabular}{lllllll}
\hline Variable & Mean & & Std. Dev. & Min & Max & Observations \\
\hline Export value (Xij)(USD,000) & Overall & 4178.593 & 23172.27 & 0.1 & 164646.1 & $\mathrm{~N}=230$ \\
& between & & 23352.77 & 1.58 & 158763.9 & $\mathrm{n}=46$ \\
& Within & & 1062.031 & -6504.67 & 10060.83 & $\mathrm{~T}=5$ \\
Exto (ton,000) & Overall & \multirow{2}{*}{96.4861} & 555.2704 & 0.004 & 3999.46 & $\mathrm{~N}=230$ \\
& between & & 559.6317 & 0.034 & 3803.65 & $\mathrm{n}=46$ \\
& Within & & 24.65931 & -118.071 & 292.2086 & $\mathrm{~T}=5$ \\
\hline
\end{tabular}

As indicated in Table 1 above, the analytical result selected variables value of export and, the volume of export in five years to 46 imports and 230observations. The analysis shows, overall, between and within results. Based on the analysis results, the overall mean of Ethiopian flower exported value is around USD 4.2 million with a minimum of USD 100 and $164,646,100$. The between analysis is over 46 countries, and the average number of years a country was observed in the value of an import. Based on this analysis, USD1580 and 158.7million minimum and maximum respectively were observed between countries. The within number refers to the deviation of each country's average from the overall average and some of those deviations are negative. As can be seen from Table 1, the minimum deviation is USD -650.5million and the maximum USD 1006083.00 from the overall average 4178.6million. Similarly, the overall average export volume of the flower was 96.5 tones with maximum and minim 0.004 and 3999.46 tons respectively.

\subsection{Empirical Analysis}

Table 2. Summary of Flower Exported Data Diagnosis Tests.

\begin{tabular}{|c|c|c|c|c|}
\hline \multirow{2}{*}{ Test } & \multicolumn{4}{|l|}{ Diagnostic Test } \\
\hline & Methods of Test & Type of statistics & Static. & Pro. Value \\
\hline Normality & Joke Bera Statistics & Chi-Square & 56.36 & 0.0000 \\
\hline Multicolonarity & VIF & Index & 1.09 & \\
\hline Panel Data Appropriate Test & Hausman Test & Chi-Square & 13.03 & 0.0000 \\
\hline Serial correlation & Breusch and Pagan Lagrangian Multiplier & Chi-Square & 379.51 & 0.0000 \\
\hline Stationary & Unit Root Test/Hadri LM & ZStatics & 11.2932 & 0.0000 \\
\hline
\end{tabular}

Source; Own diagnostic test

Before setting up the estimation models, it has to be determined whether the variables specified in the model are normally distributed random variables. The data normality test is conducted.

With the help of a graphical (histogram) and Kerner density normal distribution and numerical inspection (Shapiro-Wilk and skewness-Kurtosis tests). In addition, the Joke-Bera statistic is also used to test with the combination skeness and kurtosis. In this study, using Jokebera test was used and the results indicate residual was not normally distributed. However, after log transformation of the probability of Jokeberatest was significant to indicate that the residuals are normality distributed.

A Variable Inflation Factor (VIF) analysis was performed to check for multicollinearity problems. The result indicated that there is a multicollinearity problem. One of the remedies for the problem is to drop the variable that creates the problem. To drop variable which creates multipolarity, in VIF analysis with large value was dropped and checked for value in sequence until it's all variables VIF value is less than 10 , meaning there is no a problem of multicollinearity in the data (see Table VIF result). In this way, foreign direct investment $\left(\mathrm{Lnf}_{\mathrm{i}}\right)$ and population $\left(\mathrm{p}_{\mathrm{j}}\right)$ were correlated dropped.

The Breach and Pagan test for heteroscedasticity is applied, and the null hypothesis of homoscedastic disturbances is failed to reject 5 percent significance. The unit root test is the first step in determining a potentially co-integrated relationship between the variables. If all variables are stationary, then the traditional estimation methods can be used to estimate the relationship between the variables. The variables used in the analysis need to be stationary and/or should be co-integrated to infer a meaningful relationship from the regression. If the variables are nonstationary, a cointegration test is required. There are different techniques to identify a given panel dataset is stationary or not. The unit root test provides the order of integration at which the variables can be stationary. There are panel unit root tests like the $[12,13,15]$ in STATA version 11.2. The null hypothesis panels are stationary and alternative hypothesis some panels contain a unit root. The Lagrange multiplier (LM) test has the null hypothesis that assumes all the panels are stationary was conducted.

To select an appropriate model for the panel dataset, out of random fixed effect and pooled regression, the Hausman test result indicated that the null hypothesis which says the fixed effect is appropriate than the alternative random effect. The Hausman test result is failed to reject the null hypothesis with the probability value 0.0638 implies that the fixed effects model is appropriate. The fixed-effects model introduces heterogeneity by estimating countryspecific effects. Further double-check test was to further test between random effect model and pooled model Breusch and Pagan Lagrangian multiplier was employed and the test result showed that the null hypothesis says fixed effect model is appropriate. 
Table 3. Estimation Result.

\begin{tabular}{llll}
\hline Variable & Coef. & Std. Err. & T-test \\
\hline LnYi & 7.360554 & $(3.562041) * * *$ & $2.63^{* * *}$ \\
$\mathrm{LnYj}$ & .3280763 & .1528129 & $2.15^{*}$ \\
$\mathrm{Dij}$ & -.1287582 & .6205605 & -.21 \\
$\mathrm{LnPi}$ & 5.342 & $(47.42951) * * *$ & 2.39 \\
$\mathrm{Lnexr}_{\mathrm{j}}$ & -0.4612621 & $(0.4805365)$ & -0.96 \\
Lnfi $_{\text {Lnexr }}$ & -0.1200522 & $(0.0955468)$ & -1.26 \\
cons & -11.75213 & $\left(6.853152^{* * *}\right)$ & -1.71 \\
\hline
\end{tabular}

Source: own computation, 2016 Note: $* * *$ are significant at $1 \%$,

Values in parentheses are standard error value

As can be seen from the summary of the regression Table 3 above, in the fixed-effect model $\mathrm{R}$ squared is 0.8661 meaning that the models explained almost they are equal explained? In addition, the Wald chi2 test against the null hypothesis that all the coefficients on the independent variables in the models are zero, the null hypothesis is rejected with the probability 0.0000 and the alternative hypothesis is accepted.

Ethiopian population $\left(\mathrm{Lnp}_{\mathrm{i}}\right)$ was found to be significant at less than 5\% significance level and positive in sign with coefficient implies that a $1 \%$ increase in population results in in $5.34 \%$ increase in flower export. This analysis data doesn't consider flowers consumed for domestic use. However, domestic people are an input of labour in the flower production process. The positive sign may be because the nature of flower investment is labour-intensive. The sign is consistent with the expectation.

Ethiopian's GDP $\left(\mathrm{LnY}_{\mathrm{i}}\right)$ is significant at less than $1 \%$ significance level its and its coefficient is a positive indication that holding other factors constant; a $1 \%$ increase in Ethiopia's GDP will result from in an increase in $7.36 \%$ in flower export. This result suggests that Ethiopia's GDP is a key determinant of the country's capacity to export. A higher GDP means a higher production capacity, which in turn translates into the ability of the economy to export (more supply-side). This is consistent with the findings of Carrillo and Lee (2002) in their study of the effect of regional integration on both intraregional and intra-industrial trade in Latin America in the period 1980-1997. Using the gravity model, these authors found the exporter's GDP to be positive and statistically significant.

Ethiopian real exchange rate $\left(\operatorname{Lnexr}_{\mathrm{i}}\right)$ was also significant at less than $5 \%$ and its coefficient was negative in sign implying that, holding other factors constant, a one percent appreciation of the Ethiopian exchange rate will decrease Ethiopian flower export by 11.75 . This finding is similar to [38], in his research on what determines the export performance of Ethiopia using time series. In his conclusion, the performance of Ethiopia's exports is highly dependent on its exchange rate regime and more specifically the real exchange rate. Similar various studies have shown that the demand for the county's exports increase when its export prices fall concerning the world price.

\section{Conclusions and Recommendation}

\subsection{Conclusion}

Foreign exchange gains have the greatest impact on developing countries economic growth and development in general, and Ethiopia in particular. Ethiopia's foreign currency revenues are primarily derived from agriculture, as it is an agrarian economy. As an agrarian economy, Ethiopia's foreign currency earnings are mostly sourced from agriculture. Coffee has traditionally been counted upon as a source of foreign revenue. In recent years, there has been a push to diversify agricultural exports. Flower export is part of this diversification, policy, and plan.

This study investigated factors that determine flower export flows from Ethiopia to its 46 major trading partner countries over five years from 2010 to 2014 using a balanced short panel data type and the gravity model known for its efficiency in explaining bilateral trade performance analysis.

Regression analysis was carried out using the model that was chosen. Using the Breusch, Pagan Lagrangian multiplier, a model suitability test was undertaken to pick either a random effect, fixed or pooled model, with the fixed effect being judged to be an appropriate model at a probability value of 0.0000 significant values. As a result, the fixedeffect model was adopted in this study.

Ethiopian GDP (Ln Yi) significantly affected the Ethiopian flower expert performance because a higher GDP suggests a larger production capacity, which connects to the economy's ability to export more flowers. The study also reveals that an increase in the domestic population boosts flower export performance. This could be because flower production necessitates a larger workforce (laboure).

Moreover, Ethiopian flower export performance is negatively affected by the country's real currency rate. This could be due to the country's reliance on a small number of export commodities and quantities for foreign earnings that had a significant impact on the country's exchange rate relative to its trading partners resulted in frequent official depreciation of the Ethiopian Birr. All three factors influencing Ethiopia flower export determinants were domestic, implying that they were supply-side variables.

\subsection{Policy Recommendation}

This study suggested that there is a way to increase Ethiopia's flower export performance, which would help the economy of the country. Understanding the elements that influence flower export performance is critical for developing effective export performance improvement policies and strategies. Based on the results of the study, the following policy suggestions forwarded.

The finding of this study shows that Ethiopian GDP growth has significant positive effect on the Ethiopian export performance. This is because a large economy can produce the required amount. Therefore, it has of critical importance to maintain high and sustainability economic growth in the country. 
Similarly, Ethiopian population had a positive and significant effect on the flower export performance showing that having a productive population is a resource endowment as a source of vast labor for flower production. However, the model result indicated that the Ethiopian real exchange rate and Ethiopian flower export performance had a negative and substantial association. Therefore, to reduce exchange rate risk, the government must maintain a stable exchange rate policy to promote export depreciation of the Ethiopian Birr against importing countries currency is essential.

\section{References}

[1] Agosin, M. R., 1991. Trade Policy Reform and Economic Performance: A Review of the Issues and some Preliminary Evidence, UNCTAD Discussion Papers No. 41, UNCTAD.

[2] Aitken, N. D., 1973. The Effect of the EEC and EFTA on European Trade: A Temporal Cross-Section Analysis, American Economic Review, Vol. 63, No. 5, pp. 881-892.

[3] Alam, R., 2010. The Link between Real Exchange Rate and Export Earning: A Co-integration and Granger Causality Analysis on Bangladesh, International Review of Business Research Papers, Vol. 6, No. 1, pp. 205-214.

[4] Alemayehu Geda, 2006. Openness, Inequality and Poverty in Africa, DESA Working Paper No. 25.

[5] Anderson J. E., 2011. The Gravity Model. National Bureau of Economic Research no. 16576.

[6] Anderson, J. E., 1979. A theoretical foundation for the Gravity Equation, American Economic Review, Vol. 69, No. 1, pp. 106-116.

[7] Andrew, R., and M. Spiegel. 2004. A Gravity Model of Sovereign Lending Trade, Default and Credit, IMF Staff Papers, Volume 51, Special Issue pp 50-63.

[8] Bacchetta, M., 2007. Releasing Export Constraints: The Role of Governments, AERC Research Project on Export Supply Response Capacity Constraints in Africa. Accessed on June 19, 2013.

[9] Baldwin R., and D. Taglioni, 2006. Gravity for Dummies and Dummies for Gravity equations. Working Paper 12516. Also available on http://www.nber.org/papers/w12516.

[10] Bano, S., 2002. Intra-industry Trade and Trade Intensities: Evidence from New Zealand. Working Paper Series, Number $5 / 02$.

[11] Bergsten F., and J. Williamson (Eds), 2003. Dollar Overvaluation and the World Economy, Institute for International Economics, Washington DC.

[12] Bergstrand, J. H., 1985. The Gravity Equation in International Trade, Some Microeconomic Foundations and Empirical Evidence. Review of Economics and Statistics Vol. 67 pp. 474-81.

[13] Bergstrand, J. H., 1989. The Generalized Gravity Equation, Monopolistic Competition, and Empirical Evidence. Review of Economics and Statistic Vo. 71 pp. 143-53.

[14] Biggs, T., 2007. Assessing Export Supply Constraints:
Methodology, Data, and Measurement, AERC Research Project on Export Supply Response Capacity Constraints in Africa, Paper No. ESWP 02. Available at http://www.aercafrica.org/documents/export_supply_working _papers/BiggsT_Assessing.pdf. Accessed on June 19, 2013.

[15] Breton, R., S. Galanti, C. Hurlin, and G., Vaubourg, 2007. Does soft information matter? An application of gravity models to financial analysts' forecasts.

[16] Carrillo, C. and Li, C. A. 2002. Trade Blocs and the Gravity Model: Evidence from Latin American Countries. Working Paper, Department of Economics, University of Essex, UK.

[17] Deardorff, A. V., 1995. Determinants of bilateral trade: Does gravity work in a neo-classic world? National Bureau for Economic Research Working Paper No. 5377.

[18] Deardorff, A. V., 1998. Determinants of Bilateral Trade: Does Gravity Work in a Neoclassic World?" in J. A. Frankel (ed.), The Regionalization of the World Economy, Chicago: University of Chicago Press, pp. 7-28.

[19] Derosa, D. A., 2007. Gravity Model Analysis, Maghreb Regional Integration Peterson Institute.

[20] Egger, P., 2000. A Note on the Proper Econometric Specification of the Gravity Equation, Economic Letters, 66, 25-31.

[21] Elliott, R. J. R. and K. Ikemoto, 2004. "AFTA and the Asian Crisis: Help or Hindrance to ASEAN Intra- Regional Trade?". Asian Economic Journal 2004, Vol. 18, No. 1, pp. 1-23.

[22] Endoh, M., 1999. "Trade Creation and Trade Diversion in the EEC, the LAFTA and the CMEA: 1960-1994", Applied Economics, No. 31, pp. 207-16.

[23] ERCA, (Ethiopian Revenue and Customs Authority), 2012. Disaggregate Data on Export and Import of the Country from 1997 to 2011. Also available on http://www.erca.gov.et/index.jsp?id=import export_info. Accessed on June 30, 2013.

[24] Feenstra, R. C., 2002. Border Effects and the Gravity Equation: Consistent Methods for Estimation. Scottish Journal o Political Economy49: 491-506.

[25] Feenstra, R. C., J. R. Markusen and A. K. Rose, 1998. Understanding the Home Market Effect and the Gravity Equation: The Role of Differentiating Goods.

[26] Feenstra, R. C., J. R. Markusen and A. K. Rose, 2001. Using the Gravity Equation to Differentiate Among Alternative Theories of Trade, Canadian Journal of Economics 34: 430 47.

[27] Frankel, J., E. Stein, and S. Wei, 1995. The Natural, the Unnatural and Super-Natural, Journal of Development Economics, No. 47, pp. 61-95.

[28] Helpman E., and P. Krugman, 1985. Market Structure and Foreign Trade. Increasing Returns, Imperfect Competition and the International Economy. Cambridge, MA: MIT Press.

[29] Henry Tumwebaze Karamuriro, Wilfred Nahamya Karukuza. Determinants of Uganda's Export.

[30] Hsiao, C., 2003. Analysis of Panel Data. Second Edition, Cambridge University Press, USA. 
[31] IMF and World Bank, 2001. Market Access for Developing Countries' Exports, Prepared by IMF and World Bank Staff. Available at http://imf.org/external/np/madc/eng/042701.pdf. Accessed on July 1, 2013.

[32] Jurajda, S., 2003. Econometrics of Panel Data and Limited Dependent Variable Models. Lecture Notes Series Charles University Czech Republic.

[33] Krugman, P., M. Obstfeld and M., Melitz, 2012. International Economics: Theory and Policy, The Pearson series in economics.

[34] Lewer, J., and H. Van der Berg, 2008. A Gravity Model of Migration Management, Department Faculty Publications University of Nebraska Lincoln. Published in Economics Letters, Volume 99 number 1.

[35] Lueth E., and M. Ruiz-Arranz, 2006. A Gravity Model of Workers' Remittances, Working Paper number 06/290.

[36] Matyas, L., L. Konya and M. N. Harris, 2000. Modelling export activities of eleven APEC Countries, Melbourne institute working paper no.5/00.

[37] MoFA (Ministry of Foreign Affairs), 2007. Foreign Trade Promotion Manual for Ethiopian Diplomatic Missions, Economic and Business Affairs General Directorate, Addis Ababa, November 2007.

[38] Performance: A Gravity Model Analysis. International Journal of Business and Economics Research. Vol. 4, No. 2, 2015, pp. 45-54. doi: 10.11648/j.ijber.20150402.14.

[39] Poyhonen, P., 1963. A Tentative Model for the Volume of Trade between Countries. Weltwirtschaftliches Archiv, Vol. 90, No. 93-99.

[40] Redding, S. and A. J. Venables, 2003. Geography and Export Performance: External Market Access and Internal Supply Capacity, NBER Working Paper 9637. Available at http://www.nber.org/papers/w9637. Accessed on June 30, 2013.

[41] Shepherd, B., 2013. The Gravity Model of International Trade: A Use Guide, United Nations for Economic and Social Commission for Asia and the Pacific.
[42] Shinyekwa I., and L, Othieno, 2013. Comparing the Performance of Uganda's Intra-East African Community Trade and Other Trading Blocs: A Gravity Model Analysis. Research Series Number 100.

[43] Tewodros Mekonnen, 2012. Determinants of Export Commodity Concentration and Trade Dynamics in Ethiopia. Ethiopian Economics Association/ Ethiopian Economics Policy Research Institute (EEA/EEPRI), Working Paper No 2/ 2012.

[44] Tinbergen, J., 1962. Shaping the world economy: suggestions for an international economic policy, new York: The twentieth century fund.

[45] Todaro M., and S. Smith, 2012. Development Economics. $11^{\text {th }}$ Editions, Addison - Wesley Publishers.

[46] UNCTAD, 2005. Determinants of Export Performance: Developing Countries in International Trade, Trade and Development Index 2, pp. 49-79.

[47] UNCTAD, 2007. Market Access, Market Entry and Competitiveness, Background note by the UNCTAD Secretariat, TD/B/COM.1/83.

[48] UNCTAD, 2008. Export Competitiveness and Development in LDCs: Policies, Issues and Priorities for LDCs for Action During and Beyond UNCTAD XII, UNCTAD/ALDC/2008/1. Available http://www.unctad.org/en/docs/aldc20081_en.pdf.Accessed on June 20, 2013.

[49] UNESCAP, 2012. Interactive Trade Indicators http://www.unescap.org/tid/aptiad/trade\%20intensity.pdf accessed on July 13, 2013.

[50] Westerlund J., and F. Wilhelmsson, 2006. Estimating the gravity model without gravity using panel data.

[51] Yishak Tekalign, 2009. Determinants of Ethiopia's Export Performance: A Gravity Model Analysis. Trade and Development Discussion Paper Number 01/2009. 